\title{
Impact of certain materials againist thrips tabaci lind. (thysanoptera: thripidae) in onion fields in Qalyubia governorate.
}

\author{
EL-SAPPAGH, I. A.; E.F. , GAZIA; A.E.H.,KHALIL and B. A., BADRAN \\ Plant Protection Research Institute- Agricultural Research Center- Dokki
}

\begin{abstract}
To reduce the numbers of thrips and comparison using some chemical pesticides and other non-chemical materials, field studies were carried out to assaying the effectiveness of those materials against nymphs and adults of Thrips tabaci on onion in the Qalyubia governorate during 2014/2015 and 2015/2016 seasons. The results showed that chemical insecticide (Radiant 12\%) gave high reductions being $95.1 \%$ and $89.5 \%$ during the first season while, these were 87.1 and $81.6 \%$ during the second season for nymphs and adults of onion thrips, respectively. On the other hand, chemical insecticides Lannate 90, Mospilan and some non-chemical materials such as Garlic and Parsley oil and Chinafill 100 showed intermediate effects against nymphs and adults. The insect growth inhibitor (Admiral) showed a weak impact on nymphs and adults of onion thrips as $14.9 \& 14.3 \%$ for $1^{\text {st }}$ season and $45 \& 34.9 \%$ in the second one for adults and nymphs, respectively. In all cases, the difference between the percentages of reduction for Radiant $12 \%$ and Lannate 90 was non-significant during the first season of study while, there was a clear significant difference between both Radiant $12 \%$ and the other tested compounds during the second season. Also, the obtained results show that, there were no significant differences between reductions by the remaining tested compounds.
\end{abstract}

Key words: Onion thrips, Thr ips tabaci Lind., chemical insecticides, non-chemical insecticides.

\section{Introduction}

Onion crop in Egypt is an important field crop for both local consumption and exportation. Onion plantations are oftenly subjected to considerable insect infestations which are affected the quality and quantity. Heavy infestation by T. tabaci (more than 40 individuals / plant) cause onion yield loss up to $43 \%$ (Sato and Nakano 1990 Fournier et al. 1995). Onion plants usually are subjected to infestation by different insect pests during their different growth stages (ElSherif 1971 in Egypt; El-Bolok et al. 1990 in Egypt; Gupta et al. 1994 in India; Ciocioal et al., 2002 in Brazil; Szwejde 2005 in Poland and Mahmoud 2008 in Egypt).Several synthetic insecticides have been widely used to control onion thrips in the field (Mayer et al., 1987) because of their effective rate in bringing down pest populations. These chemical insecticides are costly and unsafe to both humans and the environment (Nault et al. 2012; Jensen and Simko, 2001) particularly to smallholder farmers who fail to follow the practices of safe handling and application of pesticide.

The conventional or non-conventional insecticides were used against $\mathrm{T}$. tabaci exhibited a high efficiency in controlling the insect (Mousa and Taha 2001; Abdel-Aziz 2002 and Khattak et al., 2006).

The aim of the present work was to study the influence of the chemical and non-chemical insecticides on the onion thrips (nymphs and adult) in the field.

\section{Materials and Methods}

This trial was carried out at Experimental Research
Station, Faculty of Agriculture, Benha University during two seasons of 2014/2015 and 2015/2016 to evaluate efficacy of some compounds against onion thrips. The trial started on April 4th and 5th for 2014 and 2015 seasons, respectively when the population of T. tabaci (adult and nymph) is known to be high. The onion seedlings (Giza 20 Variety) were planted in December $5^{\text {th }} 2014$ and $9^{\text {th }} 2015$. All the area received all agriculture practices and sprayed three times with a recommended fungicide. Seven treatments were distributed in a complete randomized block design and replicated four times. Each plot consisted of four rows each of $12 \mathrm{~m}$ long with $10 \mathrm{~cm}$ between each other rows and $5 \mathrm{~cm}$ between plants. Plots were separated by approximately $1.0 \mathrm{~m}$. to avoid drift of spraying. Other 4 plots were left without any treatment as a check. Samples were randomly as five plants from each plot. Spraying of the materials was carried out in the early morning with counted alive nymphs and adults before spraying and also after treatment with 1, 3, 7 and 10 days. Samples were placed in plastic bags and taken to the laboratory to count the insects using stereoscopic binocular. The insecticides used were as follows:-

Table 1. List of treatments and rates of applications.

\begin{tabular}{lc}
\hline Treatments & \multicolumn{2}{c}{ Rate of application } \\
& /20 L. \\
\hline Radiant 12\% (Spinetoram) & $16 \mathrm{ml}$ \\
Lannate 90 Methomyl) & $30 \mathrm{Gm}$ \\
Parsley oil (plant oil) & $200 \mathrm{ml}$ \\
Garlic oil (plant oil) & $200 \mathrm{ml}$ \\
Chinafill 100 (Calcined & \\
Aluminum Silicate Powder) & $200 \mathrm{Gm}$ \\
Mospilan 20\%SP & \\
(Acetamiprid) & $5 \mathrm{Gm}$. \\
Admiral (Pyriproxyfen 10 Ec) & $15 \mathrm{ml}$ \\
\hline
\end{tabular}


Reduction percentages of population were obtained according to the equation of Handrson and Tilton (1955).

Treatment after $\mathrm{x}$ control before

$\%$ Reduction $=1$ -

x 100

Treatment before $\mathrm{x}$ control after

\section{Data Analysis}

Data collected were analyzed using SAS 9.0 software and least significant difference (L.S.D) was used for treatment mean comparison.

\section{Results and Dissections}

\section{1 - Efficacy of the tested compounds during 2014/15 season:}

Data in Table (2) show population levels before spraying and reduction percentages of the thrips nymphs and adults caused by chemical and nonchemical insecticides after different periods from treatment. The data revealed that, all the tested compounds reduced the population density in comparison with the control. Regarding the initial effect (one day after spraying),. Radiant $12 \%$ was the highest effective compound resulting in 95.6 and 94.8\% reduction followed by Lannate 90 (92.9and 91.5\%), then Mospilan (71.8 and 58.3\%), Garlic oil (68.8 and 63.3\%), Parsley oil (61.7 and 59.3\%) and chinafill 100 (62.9 and 64.8\%). On contrary Admiral had the lowest effect (41.8 and 20.3\%) on nymph and adult, respectively.

The same observation was found three days after treatment. The highest effects on T. tabaci nymphs and adults were 98.2 and $97.8 \%$ caused by Radiant $12 \%$ treatment. Lannate 90 and Mospilan ranked the second category with 93.7 and $85.2 \%$ and 68.9 and $57.4 \%$, respectively. On the other hand, the lowest percentages of reduction were caused by Admiral Treatment as 9.3 and $17.5 \%$ for nymphs and adults, respectively.

Regarding the effect seven days after treatment, Radiant $12 \%$ exhibited also the highest impact on nymphs and adults population (90.6 and 89.1\%). while, Lannate 90, Mospilan, Garlic oil, Parsley oil and Chinafill 100 gave intermediate effectiveness. On the other hand, Admiral showed the lowest percentages of reduction (4.1 and $7.9 \%$ ) for nymphs and adults, respectively.

Table 2. Reduction percentages of T. tabaci after spraying with certain compounds during 2014/2015 season.

\begin{tabular}{|c|c|c|c|c|c|c|}
\hline \multirow{3}{*}{ Treatments } & \multirow{3}{*}{$\begin{array}{l}\text { Population / } \\
\text { plant before } \\
\text { treatment }\end{array}$} & \multicolumn{4}{|c|}{$\%$ Reduction after } & \multirow{2}{*}{ Overall mean } \\
\hline & & $24 \mathrm{~h}$. & $72 \mathrm{~h}$. & one week & 10 days & \\
\hline & & \multicolumn{5}{|c|}{ nymphs } \\
\hline Radiant & $169.8 \mathrm{a}$ & $95.6 \mathrm{a}$ & $98.2 \mathrm{a}$ & $90.6 \mathrm{a}$ & $95.9 \mathrm{a}$ & $95.1 \mathrm{a}$ \\
\hline Lannate & $75.5 \mathrm{~cd}$ & $92.9 \mathrm{a}$ & $93.7 \mathrm{a}$ & $61.8 \mathrm{ab}$ & $62.6 \mathrm{abc}$ & $77.8 \mathrm{ab}$ \\
\hline Mospilan & $97 \mathrm{c}$ & $71.8 \mathrm{~b}$ & $68.9 \mathrm{a}$ & $42.1 \mathrm{bc}$ & $68.9 \mathrm{ab}$ & $62.9 \mathrm{bc}$ \\
\hline Garlic oil & $133.8 \mathrm{~b}$ & $68.8 \mathrm{~b}$ & $59.6 \mathrm{a}$ & $68.3 \mathrm{ab}$ & $26.7 \mathrm{dc}$ & $55.9 \mathrm{bc}$ \\
\hline Parsley oil & $83 \mathrm{~cd}$ & $61.7 \mathrm{~b}$ & $2.3 \mathrm{~b}$ & $58.8 \mathrm{~b}$ & $37.5 \mathrm{bcd}$ & 40.1 cde \\
\hline Chinafill 100 & $69.5 \mathrm{~cd}$ & $62.9 \mathrm{~b}$ & $12.4 \mathrm{~b}$ & $27.1 \mathrm{dc}$ & $36.8 \mathrm{bcd}$ & $34.8 \mathrm{de}$ \\
\hline Admiral & $51.8 \mathrm{~d}$ & $41.8 \mathrm{c}$ & $9.3 \mathrm{~b}$ & $4.1 \mathrm{~d}$ & $2.2 \mathrm{~d}$ & $14.3 \mathrm{e}$ \\
\hline L.S.D & 35.69 & 19.31 & 42.83 & 30.83 & 41.35 & 27.76 \\
\hline \multicolumn{7}{|c|}{ adults } \\
\hline Radiant & $222.3 \mathrm{a}$ & $94.8 \mathrm{a}$ & $97.8 \mathrm{a}$ & $89.1 \mathrm{a}$ & $76.2 \mathrm{a}$ & $89.5 \mathrm{a}$ \\
\hline Lannate & $124.3 \mathrm{~cd}$ & $91.5 \mathrm{a}$ & $85.2 \mathrm{a}$ & $60.1 \mathrm{ab}$ & $14.9 \mathrm{~b}$ & $62.9 \mathrm{ab}$ \\
\hline Mospilan & $155.8 \mathrm{bc}$ & $58.3 \mathrm{ab}$ & $57.4 \mathrm{ab}$ & $28.6 \mathrm{bc}$ & $14.1 \mathrm{~b}$ & $39.6 \mathrm{bc}$ \\
\hline Garlic oil & $193.5 \mathrm{ab}$ & $63.3 \mathrm{ab}$ & $53.7 \mathrm{ab}$ & $52.9 \mathrm{ab}$ & $70.2 \mathrm{a}$ & $60.0 \mathrm{~b}$ \\
\hline Parsley oil & $130.3 \mathrm{~cd}$ & $59.3 \mathrm{ab}$ & $55.6 \mathrm{ab}$ & $59.8 \mathrm{ab}$ & $18.1 \mathrm{~b}$ & $48.2 \mathrm{~b}$ \\
\hline Chinafill 100 & $129.3 \mathrm{~cd}$ & $64.8 \mathrm{ab}$ & $35.2 \mathrm{~b}$ & $16.4 \mathrm{bc}$ & $28.7 \mathrm{ab}$ & $36.3 \mathrm{bc}$ \\
\hline Admiral & $100.3 \mathrm{~d}$ & $20.3 \mathrm{~b}$ & $17.5 \mathrm{c}$ & $7.9 \mathrm{c}$ & $13.8 \mathrm{~b}$ & $14.9 \mathrm{c}$ \\
\hline L.S.D & 40.72 & 42.52 & 48.06 & 47.14 & 47.63 & 28.9 \\
\hline
\end{tabular}

* Values with the same letters in column are not significant different at 5\% level of probability (One way ANOVA).

Ten days after treatment, the highest percentages of reduction of $\mathrm{T}$. tabaci nymphs and adults were 95.9 and $76.2 \%$ caused by Radiant $12 \%$ treatment while the lowest effect was 2.2 and $13.8 \%$ caused by Admiral, respectively. The remaining compounds took intermediate position showing 26.7 - $68.9 \%$ reduction for nymphs and $14.1-70.2 \%$ for adults In general, the chemical insecticide Radiant $12 \%$ gave the highest mean percentage of reduction (95.1 and $89.5 \%$ ) followed by Lannate 90 (77.8 and $62.9 \%$ ), while Admiral caused the lowest effect (14.3 and
14.9). The remaining tested compounds took intermediate effect on T. tabaci nymphs and adults. The differences between means of reduction in case of Radiant $12 \%$ and Lannate 90 were non-significant while, those were significant with Garlic oil, Parsley oil and Chinafill 100 for T. tabaci nymphs. For adults, the differences between Radiant $12 \%$ and each of Garlic oil and Parsley oil were significant and also Radiant $12 \%$ and each of Mospilan, Chinafill 100 and Admiral. 


\section{2 - Efficacy of the tested compounds during 2015/16 season:}

Data presented in table (3) revealed that, all the tested compounds reduced the population densities of thrips. The initial kill of Radiant $12 \%$ was the highest $(95.2$ and $92.0 \%$ ), but Garlic oil and Admiral gave low reduction percentages (33.0 and $42.8 \%$ ) for nymphs and adults, respectively. The remaining compounds,
Lannate 90, Mospilan, Parsley oil and Chinafill 100, took as occurred in the previous season, intermediate position $67.7,43.1,43.5$ and $54.2 \%$ for nymphs and $75.9,48.3,64.9$ and $62.1 \%$ reductions for adults, respectively. The same trend was detected after 3 days for thrips adults while, for the nymphs the trend of effectiveness changed for all the tested compounds except for Radiant $12 \%$.

Table 3. Reduction percentages of T. tabaci after spraying with certain compounds during 2015/2016 season.

\begin{tabular}{|c|c|c|c|c|c|c|}
\hline \multirow{3}{*}{ Treatments } & \multirow{3}{*}{$\begin{array}{l}\text { Population / } \\
\text { plant before } \\
\text { treatment }\end{array}$} & \multicolumn{4}{|c|}{$\%$ Reduction after } & \multirow{3}{*}{ Overall mean } \\
\hline & & $24 \mathrm{~h}$. & $72 \mathrm{~h}$. & one week & 10 days & \\
\hline & & \multicolumn{4}{|c|}{ nymphs } & \\
\hline Radiant & $31.5 \mathrm{~b}$ & $95.2 \mathrm{a}$ & $91.9 \mathrm{a}$ & $85.2 \mathrm{a}$ & $75.9 \mathrm{a}$ & $87.1 \mathrm{a}$ \\
\hline Lannate & $34.5 \mathrm{~b}$ & $67.7 \mathrm{~b}$ & $58.4 \mathrm{~b}$ & $42.1 \mathrm{~b}$ & $38.3 \mathrm{~b}$ & $51.6 \mathrm{~b}$ \\
\hline Mospilan & $36.5 \mathrm{ab}$ & $43.1 \mathrm{~cd}$ & $50.2 \mathrm{~b}$ & $33.8 \mathrm{~b}$ & $39.6 \mathrm{~b}$ & $41.7 \mathrm{bcd}$ \\
\hline Garlic oil & $32.5 \mathrm{~b}$ & $33.0 \mathrm{~d}$ & $52.2 \mathrm{~b}$ & $34.0 \mathrm{~b}$ & $28.8 \mathrm{~b}$ & $36.9 \mathrm{~cd}$ \\
\hline Parsley oil & $37 \mathrm{ab}$ & $43.5 \mathrm{~cd}$ & $62.1 \mathrm{~b}$ & $46.5 \mathrm{~b}$ & $46.6 \mathrm{~b}$ & $49.6 \mathrm{bc}$ \\
\hline Chinafill 100 & $39.5 \mathrm{a}$ & $54.2 \mathrm{bc}$ & $51.9 \mathrm{~b}$ & $48.7 \mathrm{~b}$ & $38.2 \mathrm{~b}$ & $48.3 \mathrm{bc}$ \\
\hline Admiral & $36.5 \mathrm{ab}$ & $42.0 \mathrm{~cd}$ & $30.8 \mathrm{c}$ & $42.1 \mathrm{~b}$ & $24.9 \mathrm{~b}$ & $34.9 \mathrm{~d}$ \\
\hline L.S.D & 7.22 & 15.47 & 18.03 & 19.93 & 19.05 & 13.76 \\
\hline \multicolumn{7}{|l|}{ adult } \\
\hline Radiant & $68 \mathrm{~b}$ & $92.0 \mathrm{a}$ & $83.2 \mathrm{a}$ & $79.6 \mathrm{a}$ & $71.6 \mathrm{a}$ & $81.6 \mathrm{a}$ \\
\hline Lannate & $71.3 \mathrm{~b}$ & $75.9 \mathrm{~b}$ & $70.1 \mathrm{ab}$ & $61.5 \mathrm{~b}$ & $47.1 \mathrm{bc}$ & $63.7 \mathrm{~b}$ \\
\hline Mospilan & $65.7 \mathrm{~b}$ & $48.3 \mathrm{~cd}$ & $56.4 \mathrm{bc}$ & $41.3 \mathrm{c}$ & $40.3 \mathrm{c}$ & $46.6 \mathrm{c}$ \\
\hline Garlic oil & $67.3 \mathrm{~b}$ & $51.3 \mathrm{~cd}$ & $64.5 \mathrm{bc}$ & $49.9 \mathrm{bc}$ & $42.4 \mathrm{c}$ & $51.3 \mathrm{bc}$ \\
\hline Parsley oil & $76.8 \mathrm{ab}$ & $64.9 \mathrm{bc}$ & $67.4 \mathrm{bc}$ & $64.2 \mathrm{ab}$ & $58.4 \mathrm{ab}$ & $63.7 \mathrm{~b}$ \\
\hline Chinafill 100 & $85.8 \mathrm{a}$ & $62.1 \mathrm{bcd}$ & $65.8 \mathrm{bc}$ & $65.6 \mathrm{ab}$ & $47.8 \mathrm{bc}$ & $60.3 \mathrm{~b}$ \\
\hline Admiral & $72.5 \mathrm{~b}$ & $42.8 \mathrm{~d}$ & $47.3 \mathrm{c}$ & $58.8 \mathrm{~b}$ & $31.3 \mathrm{c}$ & $45.0 \mathrm{c}$ \\
\hline L.S.D & 13.10 & 15.3 & 15.45 & 17.6 & 17.33 & 13.67 \\
\hline
\end{tabular}

*Values with the same letters in column are not significant different at 5\% level of probability (One way ANOVA).

Seven days after treatments, the highest percentages of reduction in nymphs and adults were 85.2 and $79.6 \%$ caused by Radiant $12 \%$ treatment, Lannate 90 , Garlic oil, Parsley oil Chinafill 100 and Admiral caused intermediate efficiencies 42.1, 34.0, 46.5, 48.7 and $42.1 \%$ in case of nymphs and $61.5,49.9,64.2$, 65.6 and $58.8 \%$ for adults. The lowest reduction percentages in T. tabaci population were obtained by Mospilan treatment, 33.8 and $41.3 \%$, respectively.

Regarding the data ten days after treatment, Radiant gave also the highest reduction of $\mathrm{T}$. tabaci nymphs and adults with 75.9 and $71.6 \%$, respectively. Lannate 90, Mospilan, Garlic oil, Parsley oil and Chinafill 100, as in previous season ranked of intermediate efficiency causing $38.3,39.6,28.8,46.6$, and $38.2 \%$ and $47.1,40.3,39.4,58.4$ and $47.8 \%$, respectively.. Admiral had the lower efficacy in nymphs and adults population being 24.9 and $31.3 \%$, respectively.

In general, the chemical insecticides gave clear superiority in their effects on T. tabaci nymphs and adults (87.1 and $81.6 \%$ ). The remaining materials gave the lowest effects against the nymphs (34.9 to $49.6 \%$ ) and the adults (45.0 to $63.7 \%$ ).

\section{Discussion}

The presented findings are in agreed with those obtained by Awadalla et al. \{2011) who stated that the conventional insecticide Sumithion and nonconventional insecticides, Sulfer and Biofly exhibited a high efficiency against the onion thrips population with the highest percentage of reduction. The same authors reported that Radiant $20 \%$ and Citrax oil exhibited intermediate efficiency against $\mathrm{T}$. tabaci nymphs. Sabra et al. (2005) reported that pirimiphosmethyl showed the highest effectiveness against $\mathrm{T}$. tabaci and its associated predators. On the other hand, the present results disagree with Muhammad et al, (2004) who reported that maximum decrease in the population of Thrips tabaci occurred one and three days after application was recorded in plots treated with Mospilan $20 \mathrm{Sp}$ and Tamaron.

\section{References}

Abd- El-Aziz, S.E. (2002): Laboratory and field evaluation of some biorational insecticides against onion thrips, Thrips tabaci (Lind.) (Thysanoptera: Thripidae) on garlic plant. Bull. Ent. Soc.Egypt Econ. Ser. 28:123-126.

Al-Mazraawi, E. M. (2007): Effect of fungi Beauveria bassiana on onion thrips Thrips tabaci Lindman (Thysanoptera: Thripidae) Egyptian J. Biol. Pest Control 14 (1) 50-55.

Awadalla, S. S.; M. E. El-Naggar; A. M. Taha and Omnia, F. Hamid (2011): Influence of 
conventional and non-Conventional insecticides as well as the macro- and micro elements on population density of the onion thrips Thrips tabaci lind. J. Plant Prot. and Path., Mansoura; Univ. 2 (2) (131-139).

Ciocioal, Jr, A.l.; F.H. Franca and A. 1. Ciocioal (2002): Pests associated with

Onion crops and their control. InformeAgropecuario.; 23 (2) 68-74.

El-Bolok, M.M.; I. I. Ismail and H. A. El-Shabrawy (1990): Survey and relative abundance of insects attacking onion in field and store with the accompanied natural enemies at Giza and Assuit regions. Annals of Agric. Sci., Moshtohor, 28[3]:1791-1804.

El-Sherif, A.R.A. (1971): Studies on insects infesting onion and garlic in field and storage. Ph. D, Thesis, Fac. Agric.,Cairo.Univ..Egypt 29 pp.

Fournier, F.; Boivin, G. and Stewart, R. K. (1995): Effect of Thrips tabaci (Thysanoptera:Thripidae) on yellow onion fields and economic thresholds for its management. J. Econ. Entomol. 88 (5) 1401- 1407

Gupta, R. P.; K. J. Srivastava and U. B. Pandey (1994): Diseases and insect pests of onion in India.International symposium on Allium for Tropics. Acta Horti., 358:256-269.

Hendrson, C. F. and E.W. Tilton. (1955): Tests with acaricde against the brown wheat mite. J. Econ. Etomol.; 48:157-161.

Jensen, L. and Simko, B. (2001): Alternative Methods for Controlling Onion Thrips (Thrips tabaci) in Spanish Onions. Malheur County Extension Service, Clint Shock and Lamont, Saunders, Malheur Experiment Station, Oregon State University, Ontario.

Khattak, M. K.; U. R. Manoon; S. A. S. Hussain and I. Tahir (2006): Comparative effect of neem (Azadirachta indica) oil and water extract am Baythriod TM against white fly, jassids and thrips on cotton. Pakistan. Entomol. 28 (1): 31- 37.

Mahmoud, H.H. (2008): Ecological Studies on certain insect pests of onion with special emphasis on the onion bulb fly Eumerus anoenus Loew. Ph.D. Thesis, Fac., Agric., Cairo Unvi, Egypt.

Mayer, D. F., Lunden, J. D \& Rathbone. L. (1987): Evaluation of insecticides for Thrips tabaci (Thysanoptera: Thripidae) and effects of thrips on bulb onions. Journal of Economic Entomology, 80: 930-932.

Mousa, G.A.; and A. M. Taha. (2001): Efficiency of the three oils against Aphid

fabae and Tetranyhus Uriticae. Egyptian J. Agric., Res. 80:3, 1133-1140.

Muhammad A.; Muhammad R.; Syed, A. S. and Faheem, A. (2004): Comparative efficacy of different insecticides against sucking pests of cotton. J. of Res. (Sci.), Univ., Pakistan, Vol.15, No.1, June 2004, pp. 53-58.

Nault, B.A., Hsu, C.L \& Hoepting, C.A. (2012): Consequences of co-applying insecticides and fungicides for managing Thrips tabaci (Thysanoptera: Thripidae) on onion. Pest Management Sciences (doi:10.1002/ps.3444).

Sabra, I. M.; M. A. El- Nagar and M.M.I., Khewa (2005): Efficacy of some non - chemical insecticides against Thrips tabaci Lind. and its associated predators. J. Agric. Res., 83 (2), 2005.

Sato, M.E. and Nakano, O. (1990): Influence of period of infestation of Thrips tabaci Lindeman, on the development and yield of onion plants (Allium cepa L.). Ecossistema. 15:79- 88.

Szwejda, J. (2005): Pests threatening onion in Poland. Nowosci- Warzwniczy, 40:53- 59. 


\section{تأثير بعض المواد ضد حشرة تربس البصل فى حقول البصل بمحافظة القليوبية

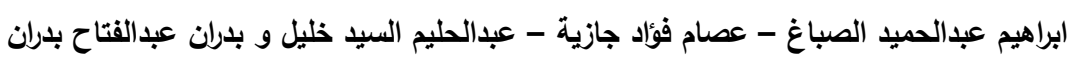 \\ معهز بحوث وقاية النباتات - مركز البحوث الزراعية - الدقى -جيزة}

للحد من تعداد التربس ولمقارنة أستخدام بعض المبيدات الكيميائية التقليدية بغيرها من المواد غير التقليدية أجريت دراسة حقلية لأختبار فعاليتها ضد

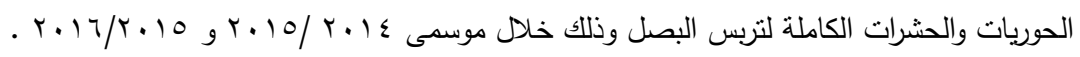

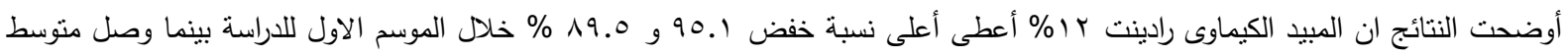

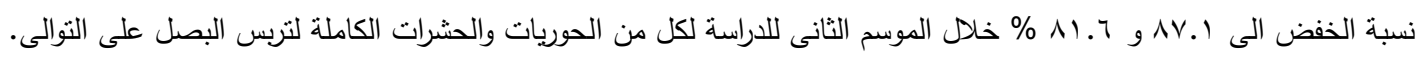

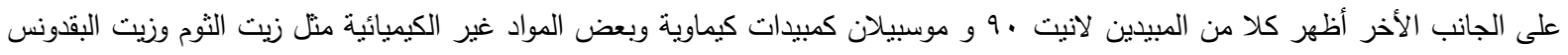
ومركب شاينافل . . 1 نسب خفض منوسطة فى تعداد الحوريات والحشرات الكاملة خلال موسمى الدراسة. كما أظهر مانع الانسلاخ أدميرال تأثيرا

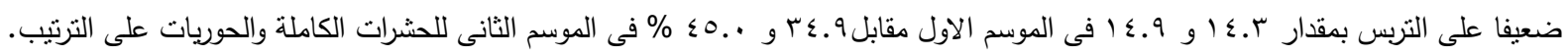

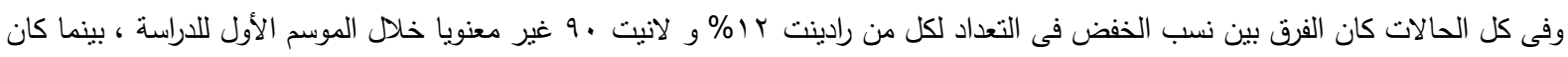

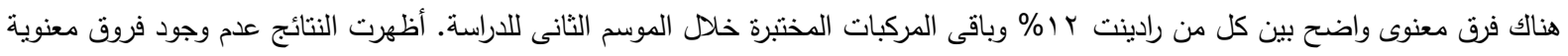

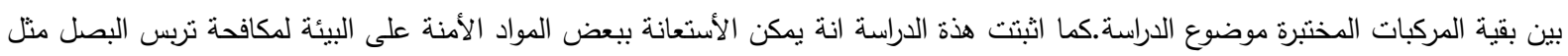
زيت الثوم وزيت البقدونس لمكافحة التربس حيث انها مواد أمنة بيئيا.. 